\title{
Coexistence of Miyofascial Trigger Points and Cervical Disc Herniation: Which One is the Main Source of Pain?
}

\author{
Miyofasiyal Tetik Nokta ve Servikal Disk Hernisi Birlikteliği: Hangisi Ağrının Esas Kaynağı?
}

Gülcan Öztürk, Duygu Geler Külcü*, ilknur Aktaş**, Ece Aydoğ ***

Gebze Fatih State Hospital, Clinic of Physical Medicine and Rehabilitation, Kocaeli, Turkey *Haydarpaşa Numune Training and Research Hospital, Clinic of Physical Medicine and Rehabilitation, istanbul, Turkey **Fatih Sultan Mehmet Training and Research Hospital, Clinic of Physical Medicine and Rehabilitation, istanbul, Turkey

***Yeditepe University Faculty of Medicine, Department of Physical Medicine and Rehabilitation, Istanbul, Turkey

\section{Summary}

Objective: The aim of this study was to investigate the coexistence of myofascial trigger points (MTrPs) and cervical disc herniations (CDH) in patients with neck and upper back pain.

Materials and Methods: In this retrospective study, patients having only MTrPs were defined as group-1, patients having only CDH were defined as group-2, patients having both MTrPs and CDH were defined as Group-3. Two hundred twenty three patients (151 females/72 males; mean age $38.2 \pm 10.1$ years) were enrolled in this study. There were 30 patients in group 1, 46 patients in group 2, 147 patients in group 3.

Results: Thirty eight patients had radiculopathy, 27 of them had $M \operatorname{TrP}(s)$. There was no significant difference in terms of $C D H$ level $(p=0.275)$ and degree of herniation $(p=0.188)$ between groups 2 and 3. There was no significant difference in terms of MTrP localisation $(p=0.684)$ between groups 1 and 3 . There was no significant difference in terms of MTrP localisations according to CDH level and nerve root compression level in groups 3.

Conclusion: MTrP and CDH coexistence is frequent. Management of the pain in the upper back region should be based on whether if the pain originates from MTrP, CDH or both.

Keywords: Neck pain, trigger points, disc herniation

\section{$\ddot{O z}$}

Amaç: Bu çalışmanın amacı boyun ve sırt ağrısı olan hastalarda miyofasiyal tetik nokta ve servikal disk hernisi birlikteliğini araştırmaktır. Gereç ve Yöntem: Bu retrospektif çalışmaya, sadece miyofasiyal tetik noktası olan 30 hasta (grup 1), sadece servikal disk hernisi olan 46 hasta (grup 2), hem miyofasiyal tetik nokta hem servikal disk hernisi olan 147 hasta (grup 3) toplam 223 (151 kadın/72 erkek; yaş ortalaması $38,2 \pm 10,1$ yll) hasta dahil edildi.

Bulgular: Çalışmaya dahil edilen hastaların 38'inde radikülopati tespit edildi. Bunların 27'sinde miyofasiyal tetik nokta mevcuttu. Grup 2 ve 3 arasında servikal disk hernisi seviyesi $(p=0,275)$ ve derecesi $(p=0,188)$ arasında istatistiksel anlamlı fark yoktu. Grup 1 ve 3 arasında miyofasiyal tetik nokta lokalizasyonu $(p=0,684)$ açısından istatistiksel anlamlı fark yoktu. Grup 3'te servikal disk hernisi ve sinir basısı düzeyine göre miyofasiyal tetik nokta lokalizasyonunda istatistiksel anlamlı fark yoktu.

Sonuç: Miyofasiyal tetik nokta ve servikal disk hernisi birlikteliği sıktır. Boyun ve sırt ağrılarının tedavisinde ağrının esas kaynağının miyofasiyal tetik nokta, servikal disk hernisi veya ikisinin birlikteliği olup olmadığı tespit edilmelidir.

Anahtar kelimeler: Boyun ağrısı, tetik nokta, disk herniasyonu 


\section{Introduction}

Myofascial pain syndrome (MFPS) is a common painful muscle disorder caused by myofascial trigger points (MTrPs) (1). MTrPs are focal, hyperirritable spots located in a taut band of skeletal muscle. The trigger points are painful on compression and may produce referred pain and referred tenderness (2). The most accepted theory for the referred pain mechanism of MTrPs is the sensitisation of nociceptive central pathways according to the Ruch convergence projection theory (3), modified by Mense (4). Another theory explains the referred muscle pain as a result of deep somatic structures (5). The results of the study by Farasyn (6), fed the hypothesis that each referred muscle pain primarily originates from local injured muscular structures which entrap afferent peripheral sensitive nerves.

Referred pain is the pain perceived in a region separate from the location of the primary source of pain. The referring pain mechanism of MTrPs is still not exactly understood but has been described as the great mimicker of numerous conditions such as radicular pain or visceral pain (7).

Upper back pain (UBP) may originate from several spinal structures including ligaments, zygapophyseal joints, muscles, discs, and compressed nerve roots. The location of pain may be similar in these conditions and determining the source or sources of symptoms can be very difficult (8).

The aim of this retrospective study was to investigate the co-existence of cervical disc herniation $(\mathrm{CDH})$ and MTrP in patients with active MTrPs in upper back muscles.

\section{Materials and Methods}

Patient selection: The medical records of patients with symptoms of neck and and upper back muscles who were admitted to Yeditepe University Hospital, Department of Physical Medicine and Rehabilitation Outpatient Clinic between January 2011 and January 2012 were reviewed. The study protocol was reviewed and approved by the university ethics committee. Among those, patients who had a cervical magnetic resonance imagining (MRI) and had a complete history and physical examination (including MTrP examination of neck and upper back muscles, Spurling test, neurologic examination) were included in the study. Patients with a history of malignancy, fibromyalgia syndrome, spinal infection, spinal surgery and metabolic diseases were excluded. Eventually, 223 patients were included the study.

Data source: The MRI results were collected and reviewed from the hospital information system. The level of the $\mathrm{CDH}$ and the degree of the herniation such as bulging, protrusion, extrusion were noted. The level of nerve root compression was noted. The MTrPs in the upper trapezius, levator scapula, rhomboid major, rhomboid minor, scalen and splenius capitis muscles were recorded since these muscles are the most affected muscles by upper back and cervical myofascial pain. In our clinic, MTrP was diagnosed according to the below criteria; 1) presence of a palpable taut band in a skeletal muscle,
2) presence of hypersensible tender spot in the taut band, 3) local twitch response elicited by the snapping palpation of the pain pattern of the MTrP in response to compression, 4) painfull limit to full stretch range of motion, and 5) spontaneous presence of the typical referred pain pattern and/or patient recognition of the referred pain as familiar. When all of these criteria were present, the MTrP was considered as active (9). Locomotor system and neurologic examination data including Spurling test, muscle strength test, sensory examination and deep tendon reflexes were collected for all patients. Patients were grouped according to the presence of MTrPs and $\mathrm{CDH}$. Group 1 only had MTrP(s). Group 2 only had $\mathrm{CDH}$. Group 3 had both $\mathrm{CDH}$ and MTrP(s). Demographic data of groups were compared. Group 2 and group 3 were compared in terms of nerve root compression level and herniation grade. Group 1 and group 3 were compared in terms of distribution of trigger points.

\section{Statistical Analysis}

Statistical Package for the Social Sciences (IBM SPSS Statistics for Windows, Version 22.0. Armonk, NY: IBM Corp) was performed for the statistical evaluation. Descriptive statistics were used for the evaluation of the demographic data and frequency of MTrPs and CDH. Differences between groups were analyzed by Mann-Whitney-U test, chi-square test and One Way ANOVA test. Significance level was considered $p<0.05$.

\section{Results}

The mean age of the patients was $38.2 \pm 10.1$ years (16-74). One hundred fifty one patients were females (68\%), and 72 were males (32\%). None of the patients had neurologic deficit. Spurling test was positive in 42 patients. Percent of ninety (38) of patients with positive Spurling test had nerve root compression. Among 193 patients with $\mathrm{CDH}, 38$ of them had the nerve root compression. Percent of seventy one (27) of the patients with nerve root compression had MTrPs. Thirty patients (13\%) had only MTrP(s) (group 1). Forty six patients (20\%) had only $\mathrm{CDH}$ (group 2). One hundred forty seven patients (66\%) had both $\mathrm{CDH}$ and MTrP(s) (group 3). Distribution of the mean age, symptom duration and gender, occupation, pain intensity and distribution among groups are presented in Table 1. Among groups there was no difference in terms of duration of the symptoms whereas there was statistically difference in terms of age and gender ( $p<0.0001$ and $p=0.0001$, respectively).

There was no significant difference in terms of $\mathrm{CDH}$ level $(p=0.275)$, nerve root compression $(p=0.442)$ and degree of herniation $(p=0.188)$ between group 2 and group 3 . Distribution of the $\mathrm{CDH}$ level and degree of the herniation of the groups are presented in Table 2. The distribution of muscles with MTrPs according to CDH levels of group 3 has been shown in Table 3. The distribution of MTrPs according to nerve root compression level of group 3 has been shown in Table 4. There was no significant difference in terms of MTrP localizations according to nerve root compression and CDH level ( $p>0.05)$. 
Table 1. Demographic characteristics of the patients

\begin{tabular}{|c|c|c|c|c|}
\hline & Group $1(n=30)$ & Group $2(n=147)$ & Group $3(n=46)$ & $\mathbf{p}$ \\
\hline Age & $32.7 \pm 6.5(17-43)$ & $38.1 \pm 10.4(16-74)$ & $41.9 \pm 9.6(25-66)$ & $<0.0001$ \\
\hline Gender & $\begin{array}{l}\text { Female/Male: } \\
20 / 30=(67 / 33 \%)\end{array}$ & $\begin{array}{l}\text { Female/Male: } \\
110 / 37=(75 / 25 \%)\end{array}$ & $\begin{array}{l}\text { Female/Male: } \\
21 / 25=(46 / 54 \%)\end{array}$ & 0.001 \\
\hline $\begin{array}{l}\text { Symptom } \\
\text { duration }\end{array}$ & $\begin{array}{l}38.1 \pm 19.5 \\
(5-720)\end{array}$ & $\begin{array}{l}167.9 \pm 29.9 \\
(10-1230)\end{array}$ & $\begin{array}{l}169.5 \pm 21.2 \\
(1-1050)\end{array}$ & 0.821 \\
\hline Occupation & $\begin{array}{l}\text { Office worker (banker, secretary, } \\
\text { etc.) } 20(\%) \\
\text { Housewife } 4(\%) \\
\text { Teacher } 4(\%) \\
\text { Student } 2(\%) \\
\text { Doctor } 0(\%) \\
\text { Nurse } 0(\%)\end{array}$ & $\begin{array}{l}\text { Office worker (banker, } \\
\text { secretary, etc.) } 114(\%) \\
\text { Housewife } 10(\%) \\
\text { Teacher } 10(\%) \\
\text { Student } 5(\%) \\
\text { Doctor } 5(\%) \\
\text { Nurse } 3(\%)\end{array}$ & $\begin{array}{l}\text { Office worker (banker, } \\
\text { secretary, etc.) } 41(\%) \\
\text { Housewife } 3(\%) \\
\text { Teacher } 2(\%) \\
\text { Student } 0(\%) \\
\text { Doctor } 0(\%) \\
\text { Nurse } 0(\%)\end{array}$ & 0.116 \\
\hline VAS & $\begin{array}{l}7.25 \pm 1.63 \\
(3-10)\end{array}$ & $\begin{array}{l}6.77 \pm 1.80 \\
(4-10)\end{array}$ & $\begin{array}{l}7.24 \pm 1.67 \\
(3-10)\end{array}$ & 0.173 \\
\hline $\begin{array}{l}\text { Distrubution } \\
\text { side of pain }\end{array}$ & $\begin{array}{l}\text { Right } 11(36.7 \%) \\
\text { Left } 7(23.3 \%) \\
\text { Both side } 5(16.7 \%) \\
\text { None } 7(23.3 \%)\end{array}$ & $\begin{array}{l}\text { Right } 40(27.2 \%) \\
\text { Left } 49(33.3 \%) \\
\text { Both side } 24(16.3 \%) \\
\text { None } 34(23.1 \%)\end{array}$ & $\begin{array}{l}\text { Right } 7(15.6 \%) \\
\text { Left } 12(26.7 \%) \\
\text { Both side } 8(17.8 \%) \\
\text { None } 19(40.0 \%)\end{array}$ & 0.0001 \\
\hline
\end{tabular}

VAS: Visual analogue scale, CDH: Cervical disc herniations, MTrPs: Myofascial trigger points, Group 1: Patients only had MTrPs, Group 2: Patients only had CDH, Group 3: Patients who had both MTrPs and CDH

\section{Table 2. Comparison of group 2 and group 3 in terms of radiculopathy level and cervical disc herniation grade}

\begin{tabular}{|c|c|c|c|c|}
\hline & & Group 2 & Group 3 & p \\
\hline \multirow[t]{4}{*}{ Radiculopathy level } & $\mathrm{C} 4$ & $0(0 \%)$ & $3(\%)$ & \multirow[t]{4}{*}{0.188} \\
\hline & $\mathrm{C} 5$ & $1(9 \%)$ & $3(\%)$ & \\
\hline & C6 & $8(73 \%)$ & $18(\%)$ & \\
\hline & C7 & $2(18 \%)$ & $3(\%)$ & \\
\hline \multirow[t]{4}{*}{ Herniation grade } & Bulging & $9(20 \%)$ & $31(21.5 \%)$ & \multirow[t]{4}{*}{0.275} \\
\hline & Protrusion & $31(67 \%)$ & $108(75 \%)$ & \\
\hline & Extrude disc & $5(11 \%)$ & $5(3.5 \%)$ & \\
\hline & Sequestered & - & - & \\
\hline
\end{tabular}

Table 3. Distribution of myofascial trigger points localizations according to nerve root compression levels of group 2

\begin{tabular}{|c|c|c|}
\hline Nerve root & Number of MTrP localisations (n) & $\mathbf{p}$ \\
\hline$C 4(n=3)$ & $\begin{array}{l}\text { M. Trapezius: } n=1 \text { (33.3\%), M. Levator scapulae: } n=1 \text { (33.3\%), M. Scalenus: } n=1 \text { (33.3\%), } \\
\text { Rhomboid major/minor: } n=0(0 \%)\end{array}$ & \multirow[t]{4}{*}{0.877} \\
\hline$C 5(n=3)$ & $\begin{array}{l}\text { M. Trapezius: } n=3(25 \%), M \text {. Splenus capitis: } n=0(0 \%), M \text {. Rhomboid major/minor: } n=3(25 \%) \text {, } \\
\text { M. Levator scapulae: } n=3(25 \%), \text { M. Scalenius: } n=3(25 \%)\end{array}$ & \\
\hline$C 6(n=18)$ & $\begin{array}{l}\text { M. Trapezius: } n=15(48.3 \%), M . \text { Splenus capitis: } n=0(0 \%), M \text {. Rhomboid major/minor: } n=5 \\
(16.1 \%), M \text {. Levator scapulae: } n=5(16.1 \%), \text { M. Scalenius: } n=6(19.3 \%)\end{array}$ & \\
\hline$C 7(n=3)$ & $\begin{array}{l}\text { M. Trapezius: } n=2(50 \%), M \text {. Splenus capitis: } n=0 \text {, M. Rhomboid major/minor: } n=1(25 \%), M \text {. } \\
\text { Levator scapulae: } n=1(25 \%) \text {, M. Scalenius: } n=0\end{array}$ & \\
\hline
\end{tabular}

\section{Discussion}

In this study, MTrPs and CDH coexistence rate was 66\% in patients with neck and UBP. Referred pain to the back from the neck region can be somatic and radicular. Pain arising from structures such as cervical intervertebral disc, zigoapofizeal joint, ligament, and muscle are somatic. Upper cervical level pain may refer to the head; lower cervical pain may refer to the chest wall, shoulder girdle, and upper limb (10). Discogenic pain without nerve root involvement is typically vague, diffuse and distributed axially and is usually non-dermatomal. In other words, discogenic pain does not follow any predictable course. 


\begin{tabular}{|c|c|c|}
\hline Level of CDH & Number of MTrP localisations (n) & $\mathbf{p}$ \\
\hline$C 2-C 3(n=2)$ & $\begin{array}{l}\text { M. Trapezius: } n=0(0 \%), M \text {. Levator scapulae: } n=0(0 \%), M \text {. Splenus capitis: } n=0(0 \%), M \text {. } \\
\text { Rhomboid major/minor: } n=1(100 \%)\end{array}$ & \multirow[t]{7}{*}{0.894} \\
\hline C3-C4 $(n=1)$ & $\begin{array}{l}\text { M. Trapezius: } n=6(37.5 \%), \text { M. Splenus capitis: } n=0(0 \%), M . \text { Rhomboid major/minor: } n=5 \\
(31.2 \%), M \text {. Levator scapulae: } n=4(25 \%) \text {, M. Scalenius: } n=1(6.2 \%)\end{array}$ & \\
\hline C4-C5 $(n=11)$ & $\begin{array}{l}\text { M. Trapezius: } n=3 \text { (42.8\%), M. Splenus capitis: } n=4(57.1 \%) \text {, M. Rhomboid major/minor: } n=0 \\
(0 \%), \text { M. Levator scapulae: } n=0(0 \%), \text { M. Scalenius: } n=0(0 \%) \text {, }\end{array}$ & \\
\hline C5-C6 $(n=6)$ & $\begin{array}{l}\text { M. Trapezius: } n=21(72.4 \%), M . \text { Splenus capitis: } n=0(0 \%), M . \text { Rhomboid major/minor: } n=2 \\
(6.9 \%), \text { M. Levator scapulae: } n=1(3.4), M \text {. Scalenius: } n=5(17.2 \%)\end{array}$ & \\
\hline C6-7 $(n=38)$ & $\begin{array}{l}\text { M. Trapezius: } n=4(12.5 \%), \text { M. Splenus capitis: } n=0(0 \%), M . \text { Rhomboid major/minor: } n=3 \\
(37.5 \%), \text { M. Levator scapulae: } n=1(12.5 \%), M \text {. Scalenius: } n=0(0 \%)\end{array}$ & \\
\hline C7-8 $(n=9)$ & $\begin{array}{l}\text { M. Trapezius: } n=1(50 \%), \text { M. Splenus capitis: } n=0(0 \%) \text {, M. Rhomboid major/minor: } n=0(0 \%) \text {, } \\
\text { M. Levator scapulae: } n=1(50 \%), \text { M. Scalenius: } n=0(0 \%)\end{array}$ & \\
\hline $\begin{array}{l}\text { Multiple levels } \\
(n=72)\end{array}$ & $\begin{array}{l}\text { M. Trapezius: } n=44 \text { (61.1\%), M. Splenus capitis: } n=2(2.7 \%), M \text {. Rhomboid major/minor: } n=12 \\
(16.6 \%), \text { M. Levator scapulae: } n=8(11.1 \%), \text { M. Scalen: } n=6(8.3 \%)\end{array}$ & \\
\hline
\end{tabular}

Fernandez-de-Las Penas et al. (11) have found a significant relationship between the presence of TrPs in the upper trapezius muscle and the presence of intervertebral joint dysfunctions at C3 and C4 vertebrae. The existence of referral pain patterns from somatic structures in the cervical spine has been demonstrated. Dwyer et al. (12) demonstrated that distension of the synovial capsules of the cervical zygapophyseal joints can refer pain beyond the immediate vicinity of the stimulated joint and may be referred peripherally to the ipsilateral shoulder and/or periscapular region. On the other hand, MTrPs may also cause referred and widespread pain by inducing central phenomenon. The nociceptive input from MTrPs can sensitize dorsal horn neuron in spinal cord and initiate central phenomenon. Further studies should investigate effect of central manifestations to MTrPs (13).

Currently, it is assumed that the cervical disc disruption can refer pain to the upper extremities (14). Referred somatic pain originating from each disc level to the neck, shoulder, and upper thoracic region has a great amount of overlap. The range of error has been found to be at least one segment higher or lower (10). We did not find a relationship between CDH level and localization of MTrPs. The reason of this result should be this overlap. On the other hand, estimation of segmental origin of referred pain by clinical examination is very hard. It should be possible only with invasive procedures such as cervical discography or zigoapofizyeal joint stimulation $(11,12)$.

The high coexistence of $\mathrm{CDH}$ and the MTrPs in our study may be a result of postural and biomechanical changes of the cervical colon due to degenerative changes of the functional unit. According to cycle of degeneration theory (15), there is a vicious circle among cumulative shear and repetitive stress, joint and disc degeneration, myofascial pain and dysfunctional kinetics. Postural distortions, which contributed to the disc herniation in the first place produce muscle pain due to a chronic spasm/strain pattern.
Another reason of referred pain to back from neck region is radicular pain. The reason of pain in upper back may be suggested as radiculopathy, since pain in the upper back can emanate from the C4-C6 roots, and pain in the middle and lower aspect of the scapula can emanate from the C7-C8 roots (16). However, there are some differences regarding the pain characteristics. Depending on the presence of the primarily motor or sensory involvement, radicular pain can be deep, dull, and achy or sharp, burning, and electric. Such radicular pain follows a dermatomal or myotomal pattern into the upper limb. Cervical radicular pain most commonly radiates to the interscapular region, although pain can radiate to the occiput, shoulder, or arm as well. Trigger point's referred pain is, usually, related to muscle activity, but sometimes it may be constant. It is reproducible and does not follow a dermatomal or nerve root distribution (17).

In a recent study, Cannon et al. (18) examined the patients referred for an electrodiagnostic study with suspected cervical radiculopathy. They found that $69 \%$ of patients referred for an electrodiagnosis with suspected radiculopathy, had a normal electromyographic study. $42 \%$ of those patients with normal electrodiagnostic findings had musculoskeletal disorders such as MFPS, shoulder impingement and lateral epicondylitis. Cannon et al. (18) concluded a referring pain in the upper back should be often originated from musculoskeletal disorders rather than a sign of radiculopathy. In this study, $79 \%$ of the patients had MTrPs and $17 \%$ of the patients had nerve root compression, supporting the consideration of Cannon et al. (18).

In the recent literature, it has been shown that the population with mechanic neck pain increased prevalence of active MTrPs in suboccipital muscles. In another study, patients with acute whiplash injury have increased MTrPs in levator scapulae muscle (13). Sarı et al. (19) investigated active trigger point frequency in patients with radiculopathy. Although it has been found that active MTrPs are more frequent in patients with radiculopathy, no particular muscle with MTrPs has been detected (13). In 
our study, it was found that the most of the patients (71\%) with nerve root compression had $\mathrm{MTrP}(\mathrm{s})$ but contrary is not effectual. Only $18 \%$ of the patients with $\operatorname{MTrP}(\mathrm{s})$ had nerve root compression. It should be considered that nerve root compression may cause MTrP but most of the MTrPs exist because of other reasons. In our study, the correlation between the level of nerve root compression and the MTrP localization was not found to be related. For example, in patients with C6 nerve root compression had most of the MTrPs in trapezus muscle. However, it was expected to be scalenius muscle due to the muscles' nerve root supply. The reason of this result should be the small number of patients with nerve root compression and should be a type II error.

There are a number of limitations in the current study that should be recognized. One of these limitations is the retrospective study design. Another limitation is incomplete data about axial localization of $\mathrm{CDH}$ such as central, lateral, foraminal or extraforaminal due to the retrospective design of the study. To minimize the impact of these limitations, prospective long term studies should be performed in the future.

\section{Conclusion}

As a result, the pain radiating from the neck should be evaluated in more detail. Regardless of the source of pain, trigger points that may accompany or trigger points can be a source of pain alone. In order to achieve success in treatment, patients must be evaluated in terms of the presence of the trigger point and treatment regimens for MTrPs should be organized as well.

The authors have no conflicts of interest to declare.

\section{Ethics}

Ethics Committee Approval: Yeditepe University Ethics Committee (Approval number: 235), Informed Consent: It was taken.

Peer-review: External and Internal peer-reviewed.

\section{Authorship Contributions}

Concept: Duygu Geler Külcü, Illknur Aktaş, Ece Aydoğ, Design: Duygu Geler Külcü, Ece Aydoğ, Data Collection or Processing: Gülcan Öztürk, Duygu Geler Külcü, Analysis or Interpretation: Gülcan Öztürk, Duygu Geler Külcü, Literature Search: Gülcan Öztürk, İlknur Aktaş, Writing: Gülcan Öztürk, Duygu Geler Külcü.

Conflict of Interest: No conflict of interest was declared by the authors.
Financial Disclosure: The authors declared that this study has received no financial support.

\section{References}

1. Alvarez D, Rockwell P. Trigger points: Diagnosis and management. Am Fam Physician 2002;65:653-60.

2. Simons DG, Travell JG, Simons LS. Myofascial pain and dysfunction: the trigger point manual. Baltimore: Williams\&Wilkins, 1999.

3. Ruch TC. Pathophysiology of pain. In: Ruch TC, Patton HD, editor. Physiology and biophysics. Philadelphia: Saunders; 1965.p.34563.

4. Mense S. Referral of muscle pain. Am Pain Society J. 1994;3:1-9.

5. Giamberardino M. Referred muscle pain/hyperalgesia and central sensitisation. J Rehabil Med 2003;41:85-8

6. Farasyn A. Referred muscle pain is primarily peripheral in origin: The "barrier-dam" theory. Med Hypotheses 2007;68:144-50.

7. Trigger Point Formation. Advanced Therapy Instıtute. 2006. Available from: www.advancesintherapy.com/.

8. Ohnmeiss DD, Vanharanta H, Ekholm J. Degree of disc disruption and lower extremity pain. Spine 1995;22:1600-5.

9. Rao R. Clinical syndromes of neck pain and cervical radiculopathy. In: Rothman RH, Simeone FA editor. The Spine. Philadelphia: WB Saunders Co; 2006.p.775-84.

10. Bogduk N. Innervation and pain patterns of the cervical spine. In: Grant R, editor. Physical Therapy of the Cervical and Thoracic Spine. New York: Churchill Livingstone; 2002.p.61-72.

11. Fernandez-de-Las Penas C Fernandez J, Miangolarra JC. Musculoskeletal disorders in mechanical neck pain: Myofascial trigger points versus cervical joint dysfunctions. A clinical study. J Musculoskel Pain 2005;13:27-35.

12. Dwyer A, April C, Bogduk N. Cervical zygapophyseal joint pain patterns I: A study in normal volunteers. Spine 1990;15:453-7.

13. Lluch E, Nijs J, De Kooning M, Van Dyck D, Vanderstraeten $R$, Struyf $F$, et al. Prevalence, Incidence, Localization, and Pathophysiology of Myofascial Trigger Points in Patients With Spinal Pain: A Systematic Literature Review. Manipulative Physiol Ther 2015;38:587-600.

14. Slipman CW, Plastaras C, Patel R, Isaac Z, Chow D, Garvan C, et al. Provocative cervical discography symptom mapping. Spine J 2005;5:381-8

15. Fernandez-de-Las-Penas C, Alonso-Blanco C, Miangolarra JC. Myofascial trigger points in subjects presenting with mechanical neck pain: A blinded, controlled study. Man Ther 2007;12:29-33.

16. De Palma MJ, Slipman CW. Treatment of common neck problems. In: Braddom RL editor. Physical Medicine and Rehabilitation 3rd editon. Philadelphia: WB Saunders Co; 2007.p.797-825.

17. Yunus MB. Fibromyalgia syndrome and myofascial pain syndrome: Clinical features, laboratory tests, diagnosis, and pathophysiologic mechanisms. In: Rachlin ES, editor. Myofascial pain and fibromyalgia: Trigger point management. St Louis: Mosby; 1994.p.3-29.

18. Cannon DE, Dillingham TR, Miao $H$, Andary MT, Pezzin LE. Musculoskeletal disorders in referrals for suspected cervical radiculopathy. Arch Phys Med Rehabil 2007;86:1256-9.

19. Sarı H, Akarırmak Ü, Uludağ M. Active myofascial trigger points might be more frequent in patients with cervical radiculopathy. Eur J Phys Rehabil Med 2012;48:237-44. 